Canadian University Music Review

Canadian University Music Review

Revue de musique des universités canadiennes

\title{
Susan Fast. In the Houses of the Holy: Led Zeppelin and the Power of Rock Music. Oxford: Oxford University Press, 2001. vii, 247 pp. ISBN 0-195-14723-5 (paperback)
}

\section{Glenn T. Pillsbury}

Volume 23, numéro 1-2, 2003

URI : https://id.erudit.org/iderudit/1014527ar

DOI : https://doi.org/10.7202/1014527ar

Aller au sommaire du numéro

\section{Éditeur(s)}

Canadian University Music Society / Société de musique des universités canadiennes

\section{ISSN}

0710-0353 (imprimé)

2291-2436 (numérique)

Découvrir la revue

Citer ce compte rendu

Pillsbury, G. T. (2003). Compte rendu de [Susan Fast. In the Houses of the Holy: Led Zeppelin and the Power of Rock Music. Oxford: Oxford University Press, 2001. vii, 247 pp. ISBN 0-195-14723-5 (paperback)]. Canadian University Music Review / Revue de musique des universités canadiennes, 23(1-2), 221-223. https://doi.org/10.7202/1014527ar

All Rights Reserved (C Canadian University Music Society / Société de musique des universités canadiennes, 2004
Ce document est protégé par la loi sur le droit d'auteur. L’utilisation des services d'Érudit (y compris la reproduction) est assujettie à sa politique d'utilisation que vous pouvez consulter en ligne.

https://apropos.erudit.org/fr/usagers/politique-dutilisation/ 
Susan Fast. In the Houses of the Holy: Led Zeppelin and the Power of Rock Music. Oxford: Oxford University Press, 2001. vii, 247 pp. ISBN 0-195-14723-5 (paperback).

Perhaps the most significant aspect of Susan Fast's In the Houses of the Holy is its musicological dedication to a single artist within the realm of contemporary cultural theory-driven popular music studies. After two decades struggling at the margins of academic musicology, popular music studies in the 1990s finally reached a point where a single-artist project such as Fast's could be possible, as well as a useful contribution to the field. In many ways In the Houses of the Holy is a watershed and a compendium, summarizing the issues of popular music studies at the end of the twentieth century. Paradoxically, even as the concept of a single artist's career as the dominant investigative pole of scholarly music studies has been greatly devalued from within more traditional areas of musicology, it has remained important for the development of popular music studies. And this is where Fast's book really succeeds. It is not simply a stylistic biography of a single artist, blithely replicating the academic fetish for individual greatness. Rather, In the Houses of the Holy focuses on Led Zeppelin but ultimately aims toward usefulness well beyond that band. It is by no means the first scholarly book on a single popular music artist, but it is Fast who most usefully (and most interestingly) succeeds in this kind of project. Moreover, in doing so Fast generally remains cognizant of the successful methodologies and ideas that have come before, and which have even enabled her book to be written in the first place.

With the above comments in mind, I was somewhat surprised at how little time Fast spends discussing how a book on a single artist should work when many of the ideas regarding the primacy of individual creators (understood through the metaphors of "genius" and "canon") have been so thoroughly deconstructed (largely by popular music scholars). She quite clearly sees In the Houses of the Holy along some familiar scholarly lines: celebrating Led Zeppelin's music and carving out a place among rock's "elite" by rescuing the band from misguided rock critics and misinformed musicologists. Both of those lines are perhaps understandable. After all, why write about something if you're not passionate about it? Moreover, setting the record straight is always important. Still, Fast largely neglects contextualizing her version of "celebration" as distinct from that of the non-academic presses. The result of this missing context allows a stamp of musicological objectivity ("Musicologist Explains Led Zeppelin") to linger throughout her text. That Fast uncritically begins the Introduction to In the Houses of the Holy with a statement by one fan "so happy that after years of being put down for worshipping such a 'déclassé' band ... someone like you is giving their oeuvre the deserved attention of an academic" (p. 3) is a remarkable move: it continues the image of the academy as the final legitimizing authority for cultural content. The ultimate danger, therefore, in Fast's particular approach toward celebrating Led Zeppelin is to allow familiar ideologies regarding music, musicians, and academics to remain unchallenged. 
Each of the five chapters of In the Houses of the Holy circles around a single song or group of songs, approaching them from a wide range of areas. Fast has availed herself of useful writings across a range of cultural studies, and the perspectives she introduces are informative to the degree that the example given by In the Houses of the Holy provides important guides for future studies in rock music. Moreover, Fast provides extremely close readings of Led Zeppelin's music, of which she obviously has an exceedingly intimate knowledge. The content is rich and elegantly written as Fast moves through theories of textuality/intertextuality, myth/epic, appropriation/exoticism, the body/representation, etc. as they inform such songs as "Dazed and Confused," "Stairway to Heaven," "Kashmir," and "Whole Lotta Love." One important current running throughout is the argument for interpretive precision in discussing rock musicians. Indeed, part of Fast's efforts toward "rescuing" Led Zeppelin stem from her desire to treat individual artists (and their artistic expression) on a more individualized basis. Her exploration of "Kashmir," for example, takes great care to parse the specific characteristics of exotic and orientalist imagery in this song, and resists the kind of blanket suspicion of cross-cultural borrowings that typically mark reactions to such things by popular music studies. Here, Fast willingly enters into the debates over how exoticism can be defined and discussed, as well as making the important argument that every cross-cultural interaction has different meanings.

However, there are some pitfalls to the broad reach of In the Houses of the Holy. For instance, in a useful discussion of "the riff" in chapter 4, Fast is more interested in surveying Mark Johnson's system of schema itself rather than coming to specific conclusions or interpretations about any particular riff by Led Zeppelin. In a sense she engages in an act of cataloging that, while an excellent presentation on the potential value of Johnson's ideas-Fast's close reading of riffs is long overdue in popular music studies-doesn't really tell us very much about Led Zeppelin in the end. Curiously missing among all of her larger topics, moreover, is musical analysis, or the question of how to talk about musical detail in popular music. Perhaps in order to keep her focus on the lived experience of music, Fast largely forgoes entering into the polemics of Roman numeral analysis and notation-based methodologies, clearly preferring to adopt those techniques without much comment.

For a book that repeatedly calls upon Robert Walser's groundbreaking work on heavy metal, In the Houses of the Holy all but avoids the position Led Zeppelin occupies in broader discussions of metal. ${ }^{1}$ Regardless of how much Robert Plant detested his band's assignment to that genre, millions of people have regularly cited Led Zeppelin in debates over how to tell the history of metal. Indeed, Plant's very resistance to the label offers up a tantalizing avenue of inquiry. Importantly, certain places in the text would benefit from some acknowledgement of the style traits associated with metal in order to explain the particular musical moments under discussion. For example, in chapter 2 Fast delves into the varying harmonic functions of the A chord in the later sections of "Stairway to Heaven," pointing

1 Robert Walser, Running With the Devil: Power, Gender and Madness in Heavy Metal Music (Hanover, NH: Wesleyan University Press, 1993). 
out that the chord first serves as a clear point of closure before being transformed, pivot-like, into a point of departure (p. 66). This is all well and good, but the chord sequence which departs on the A chord (A-G-F) is a textbook example of heavy metal's "Aeolian progression:" i-VII-VI (-VII), a trait absolutely crucial to the musical identity of the genre. Of course, the term "heavy metal" was not in wide circulation in 1971 when "Stairway to Heaven" was recorded, and certainly the early stylistic history of metal is one of the more murky areas in all of popular music. Nevertheless, the lack of engagement in this area serves to reinforce the notion that Led Zeppelin stood outside these kinds of questions.

Chapter 5, "Whole Lotta Love: Performing Gender," is one of the most important pieces of rock music scholarship in the last ten years. In it, Fast moves to finish off definitively one of the most enduring myths about gender and rock music: the concept of "cock rock." Under increasing fire in recent years from a number of scholars, cock rock represented a spectrum of ideas emanating from the simplistic gender binary of rock/masculine, pop/feminine, and the equally powerful corollary that rock music and male rock stars directly reinscribe a masculinist hegemonic social order. Fast provides a thorough survey of the mechanics of how rock music was made to be "unmistakably phallic" (p. 164) as well as an interesting historiographical discussion of the concept of cock rock. Her ultimate claim (building off Walser's work on glam metal in the 1980s and Judith Butler's theories on gender performativity) asserts that women engage with rock in a variety of ways with respect to gender and sexuality. Here, her own experiences are particularly useful, as she discusses the development of her (fan) relationship to the members of Led Zeppelin in the 1970s. In particular, Fast explains her response to the band as providing both the feeling of being powerful and attractive. Her survey participants, particularly the women, generally agree: they describe some amount of sexual attraction but are also insistent that it formed only a part of the overall appeal of Led Zeppelin's music and lyrical imagery. Moreover, Fast finds that her female participants' attraction to the band members was an enabling experience, and one which Fast sees as strongly contesting Laura Mulvey's concept of the "male gaze." In the end, Fast's accomplishment is to argue compellingly the case for female fans' sexual attraction to male rock stars as an attraction that can be $o k$.

Overall, In the Houses of the Holy offers a significant contribution to the musicological study of popular music, and the scope of the book allows it to be useful beyond Led Zeppelin. Fast's desire for precision with respect to issues of representation and her careful attention to musical detail provide useful models for future work on rock. Finally, she has raised the bar for studies on single artists, and even if quibbles remain regarding the issues of "celebration" and "rescue," In the Houses of the Holy marks an important moment in the coming of age of popular music studies.

Glenn T. Pillsbury 